\title{
A study on the stability of international reserve currency
}

\author{
Kaida Li \\ School of Economics and Resource Management, Beijing Normal University
}

\begin{abstract}
This article uses the dynamic analysis of the small country open economic framework (Obstfeld and Rogoff) to establish a basic supply and demand model of two countries, which solves the stable condition that the international reserve currency reaches the balance. The equilibrium stability condition of reserve currency is that the solvency growth rate of reserve currency countries is not lower than the real yield of reserve currency and the actual output growth rate of the non-reserve currency countries, while the reserve currency countries should have larger economic volume. The test of the Bretton Woods system and the contemporary international reserve currency system with stable conditions shows that the Bretton Woods system and the contemporary international reserve monetary system do not meet the stability conditions.
\end{abstract}

\section{Indexing terms/Keywords}

International monetary system; Reserve currency stability; Bretton Woods system

\section{Academic Discipline And Sub-Disciplines}

International Finance

\section{SUBJECT CLASSIFICATION}

Finance

\section{TYPE (METHOD/APPROACH)}

\author{
Theoretical Research
}

\section{Introduction}

In the International monetary system, reserve currency plays a basic function of Exchange media, accounting unit and value storage (Truman,1999), which directly affects the monetary relationship between the currencies of the International monetary system, Exchange rate arrangement and balance of payments adjustment mechanism, so the international reserve monetary system has become the system foundation of the International monetary system, and its stability has pretty important significance to the stability of the world economy, trade and political.

International reserve currency experienced from the gold, silver and other commodity currencies to today's dollar-oriented credit currency, each time the change means violent turbulence of the international monetary system. The collapse of the Bretton Woods system has proclaimed the end of the era of the gold-dominated reserve currency system, and the international reserve currency system experienced a tumultuous times since the 1980s to today's subprime crisis, and each of these upheaval has brought huge economic losses to the world.

What is the source of the international reserve currency turmoil? What conditions do they need to stabilize? How can we improve the stability of our current international reserve currency system? The answer to these questions is pretty important, but there is still a lack of normative proof of the above problems.

This article uses the small country open economic dynamic analysis framework of the Obstfeld and Rogoff to establish a basic supply and demand model for the international reserve currencies of the two countries, and to solve the stability conditions of supply and demand balance. The stability conditions of the Bretton Woods system and the post-Bretton International reserve currency system were tested.

\section{Review}

The research on the stability of international reserve currency has always been the focus of scholars at home and abroad.

Many scholars study the stability of international reserve currency from the perspective of saving demand of reserve currency. Caballero (2008) studies the savings-type demand for reserve currencies from non-reserve currency countries, and finds that trade surplus countries such as emerging markets are less able to provide adequate financial assets for domestic savings because of low financial development, The surplus countries funds will flow into the United States and other countries with high levels of financial development, such as global imbalances, low interest rates and a sharp increase in dollar-denominated assets; $\mathrm{Xu}$ Jianwei and Yao propose that the United States, the United Kingdom and other major providers of financial services, China and other major manufacturers, in this division of labor, the non-reserve currency countries based on savings demand increased reserve currency accumulation. There are also scholars who study the precautionary needs of reserve currencies. Obstfeld, and so on (2008) point out that the capital outage will trigger a currency crisis, the more dangerous capital increase, the sudden capital outage will produce external depletion, capital increase will 
produce internal exhaustion. Non-reserve currency countries will consider the possibility of capital increase and maintain their financial stability in the process of making foreign exchange reserve demand.

As the world's most important global currency, the stability of the US dollars in the contemporary international monetary system is also an important issue. The stability of the dollar reserve currency in the modern international monetary system has formed a diametrically opposed two factions: Obstfeld and Rogoff (2007) represent the view that dollar reserve assets are unstable and that the dollar will be adjusted to a balanced level in the form of sharp depreciation; and the other scholars think that the dollar reserve assets are relatively stable in terms of valuation effect, while the United States has been in the balance of payments deficit, which gains positive valuation effects.

The problem of the instability of the reserve currency has further aroused the discussion of the reform of the international monetary system in the academic circle. Obstfeld points out that the fundamental task of the reform of the international monetary system is to find alternative currencies to provide international liquidity; Farhi (2011) put forward that the future of the world is multipolar, which means the multipolarity of international monetary system is also tendency, and RMB will play an increasingly important role in the international monetary system as well; Talor (2013) further states that the internationalization of RMB helps to avoid the crisis of reserve currency, thus safeguarding the stability of reserve currency and playing a vital role in the stability of the international monetary system.

\section{The oretical framework}

The reserve currency countries are central to the international monetary system, and Rey(2013) describes the global financial cycle phenomenon, indicating that monetary policy in the major reserve currency countries (the United States) affects the capital flows in other countries, and credit terms such as asset prices. The non-reserve currency countries are in fact the recipient of world interest rate prices. To simplify the analysis, we view a small number of reserve currency countries as reserve currency country $A$ and a large number of non-reserve currency states as non-reserve currency country $B$. Because of the large number of non-reserve currency countries and the price of world interest rate recipients, such resumption allows to ignore the interplay between the non-reserve currency countries and the reserve-currency countries, thus focus on the interaction of the two groups of countries. We studied the stability of reserve currencies using the open economic dynamic analysis framework of small countries with Obstfeld and Rogoff(1996).

\subsection{Non-reserve currency countries' demand for reserve currencies}

This paper discusses the stability of reserve currency and adopts the concept of reserve currency in broad sense, that is, all external liabilities of reserve currency including reserve currency countries. Non-reserve currency countries hold reserve currencies for the main purposes of trading, saving and prevention. This paper focuses on the savings demand of the nonreserve currency countries, which embodies the savings demand as a tool for the residents to cross the period smoothly. Transactional demand is smaller than other requirements and is included in the demand for savings and preventative demand, ignoring the transaction demand does not have a significant impact on our conclusion, the preventive demand will introduce the uncertainty, increase the complexity of the analysis, can be used as the expansion of the basic model of this paper, in the follow-up research to enrich and expand.

The demand for international reserves by non-reserve currency countries cannot be met through a net outflow of capital from reserve-currency states, which can only be expressed through the current account deficit of the reserve currency countries:

$$
R_{t+1}^{B}-R_{t}^{B}=C A_{t+1}^{B}
$$

$R_{t}^{B}$ represents the amount of reserve currency held at the end of the term for a representative resident of a non-reserve currency country $\mathrm{B}, C A_{t+1}^{B}$ represents the current account balance in the period of $\mathrm{T}+1$ for representative residents of the Country $\mathrm{B}$, which forms the reserve of the country in the reserve currency. To simplify, without considering the government, there are:

$$
C A_{t+1}^{B}=X M_{t+1}^{B}+r R_{t}^{B}=Y_{t+1}^{B}+r R_{t}^{B}-C_{t+1}^{B}
$$

$X M_{t+1}^{B}$

${ }_{t+1}^{B}$ represents $B$ representative resident of country $t+1$ Trade Net exports of the period, $\mathrm{R}$ the actual rate of return for the reserve currency, $Y_{t+1}^{B}$ represents B representative resident of country $\mathrm{t}+1$ output of the period, $C_{t+1}^{B}$ represents B representative resident of country $t+1$ consumption of the period.

Binding ( 1 ) and ( 2 ):

$$
C_{t+1}^{B}=Y_{t+1}^{B}-R_{t+1}^{B}+(1+r) R_{t}^{B}
$$


And this expression for non-reserve currency countries B consumer budget constraints for representative residents. If the utility function is assumed to be additive, the utility of a representative resident for a lifetime is:

$$
U_{t}^{B}=E_{t}\left[\sum_{i=0}^{\infty} \beta^{i} u^{B}\left(C_{t+i}^{B}\right)\right]
$$

To solve this optimization problem, the Euler equation of representative inhabitant consumption is obtained:

$$
u^{B^{\prime}}\left(C_{t}^{B}\right)=\beta(1+r) u^{B^{\prime}}\left(C_{t+1}^{B}\right)
$$

The upper-style indicates that the marginal income of representative residents increasing one unit of current consumption

equals marginal cost. Suppose B A representative resident of a country is risk averse, so it can be set:

$$
u^{B}(C)=\frac{C^{1-\delta^{B}}}{1-\delta^{B}}
$$
define $\alpha=(1+r)^{1 / \delta^{B}} \beta^{1 / \delta^{B}}$, getting a non-reserve currency country $\mathrm{B}$ the dynamic equation of the reserve currency that a representative resident of a country is willing to hold:

$$
R_{t+1}^{B}=(1+\alpha+r) R_{t}^{B}-\alpha(1+r) R_{t+1}^{B}+Y_{t+1}^{B}-\alpha Y_{t}^{B}
$$

$\underset{\text { Thus }}{{ }^{B}}{ }^{B}=\frac{R_{t}^{B}}{Y_{t}^{B}}$

, to indicate the proportion of the reserve currency assets of the non-reserve currency countries to the total output, assuming $\mathrm{B}$ the growth rate of the country is $\mathrm{g}$, equation ( 6 ) by dividing both sides by $Y_{t}^{B}$ :

$$
\begin{gathered}
\hat{R}_{t+1}^{B}-\frac{\alpha}{1+g} \hat{R}_{t}^{B}+\frac{1+g-\alpha}{r-g}=\frac{1+r}{1+g}\left(\hat{R}_{t}^{B}-\frac{\alpha}{1+g} \hat{R}_{t-1}^{B}+\frac{1+g-\alpha}{r-g}\right) \\
\rho_{t}=\hat{R}_{t+1}^{B}-\frac{\alpha}{1+g} \hat{R}_{t}^{B}+\frac{1+g-\alpha}{r-g}{ }^{B} \rho_{t+1}=\frac{1+r}{1+g} \rho_{t}, \text { cumulative stack: } \\
\hat{\rho}_{t+1}{ }^{B}=\left(\frac{1+r}{1+g}\right)^{t} \rho_{1} \\
R_{t+1}-\frac{\alpha}{1+g} \hat{R}_{t}^{B}+\frac{1+g-\alpha}{r-g}=\rho_{1}\left(\frac{1+r}{1+g}\right)^{t}
\end{gathered}
$$

The demand equation of reserve currency can be obtained by the above calculation:

$$
R_{t+1}^{B}=\left\{\frac{\rho_{1}\left(1+g^{B}\right)}{1+r-\alpha}\left(\frac{1+r}{1+g^{B}}\right)^{t}+\left[R_{0}^{B}-\frac{\rho_{1}\left(1+g^{B}\right)}{1+r-\alpha}+\frac{1+g^{B}}{r-g^{B}}\right]\left(\frac{\alpha}{1+g^{B}}\right)^{t}-\frac{1+g^{B}}{r-g^{B}}\right\} Y_{t}^{B}
$$

The demand of reserve currency is the function of the output of the reserve currency countries, the actual output growth rate and the actual yield of reserve currency. The demand for reserve currency increases with the output of the non-reserve currency countries, and the actual yield of the reserve currency, the actual growth rate of the non-reserve currency countries, is uncertain.

\subsection{Reserve money supply and solvency}

In the gold standard period, the reserve currency (gold) itself has value, after the gold standard system ended, the sovereign currency becomes the reserve currency, but the sovereign currency itself has no value. Reserve currency Country $A$ the ability to supply a reserve currency, i.e. the capacity of a reserve currency state to be indebted, is bound by its solvency:

$$
R_{t}^{A}=k_{t} T_{t}^{A}
$$

In which $R_{t}^{A}$ Supply of reserve currency State reserve currency, $T_{t}^{A}$ the solvency of the State, ${ }_{t}$ represents the ratio of repayment support for reserve currency countries to issue reserve currencies, The maximum repayment support ratio that 
can be accepted. Maximum Reimbursement support ratio Influenced by the world economic operation and the substitution of reserve currency. When the economic crisis occurs, the willingness of creditors to provide financing is weakened, The choice of the creditor is limited when the reserve currency can substitute bad, ${ }^{t}$ remain relatively high.

However, although it can remain high, but $\bar{k}_{t}$ by no means infinitely large, when the reserve-currency state reimburses more than $\bar{k}_{t}$, reserve currency countries cannot maintain the stable value of the reserve currency. Currency stability is an important feature of reserve currency and is a prerequisite for widespread acceptance and use by other countries (Farhi , etc.,). Once the reserve currency countries are unable to maintain the stable value of the reserve currency, other countries will reduce or even abandon their acceptance and use of the currency, and their reserve currencies will gradually lose their status.

Under the Bretton Woods system, the dollar became the new international reserve currency. The Bretton Woods agreements provide for a fixed ratio of the dollar to gold and a fixed proportion of the currencies of other countries to the dollar. The United States provides the world with a reserve currency, yet America's reserve-money supply is not unlimited, and it is constrained by the solvency of the US, which holds the US gold reserves. As the world economy grows, the need for the non-reserve currency countries to increase rapidly, while the U.S. holdings of gold reserves by the world's gold production constraints, the United States to increase the repayment support than the accepted maximum repayment support than the United States to maintain the reserve currency of the dollar stability, the Bretton Woods system eventually collapsed.

After the collapse of the Bretton Woods system, the value of the dollar is no longer tied to gold, and gold is bound to the supply of reserve money. Reserve currency as a sovereign credit currency, its supply capacity is subject to new solvency, that is, the reserve currency country's financial capacity of the United States (Farhi , etc.,).

\subsection{Balanced stability of reserve currency}

The equilibrium conditions for reserve currencies are: $R_{t}^{B}=R_{t}^{A}$. Combining the demand equation of the reserve currency with the supply equation, substituting the formula:

$$
k_{t}=\left[\frac{\rho_{1}\left(1+g^{B}\right)}{1+r-\alpha}\left(\frac{1+r}{1+g^{B}}\right)^{t}+c\left(\frac{\alpha}{1+g^{B}}\right)^{t}-\frac{1+g^{B}}{r-g^{B}}\right] \frac{Y_{t}^{B}}{T_{t}^{A}}
$$

The equilibrium stability condition of reserve currency is the repayment support ratio of reserve currency issuer $k_{t}$ convergence, when divergent, $k_{t}$ will exceed the maximum support ratio, the reserve currency countries cannot maintain the stable value of the reserve currency and the reserve currency system is unstable, so the necessary conditions for convergence are:

$$
\begin{gathered}
\lim _{t \rightarrow \infty} \frac{k_{t+1}}{k_{t}} \leq 1 \\
\lim _{t \rightarrow \infty} \frac{k_{t+1}}{k_{t}}=\lim _{t \rightarrow \infty} \frac{\frac{\rho_{1}\left(1+g^{B}\right)}{1+r-\alpha}\left(\frac{1+r}{1+g^{B}}\right)^{t+1}+c\left(\frac{\alpha}{1+g^{B}}\right)^{t+1}-\frac{1+g^{B}}{r-g^{B}}}{\frac{\rho_{1}\left(1+g^{B}\right)}{1+r-\alpha}\left(\frac{1+r}{1+g^{B}}\right)^{t}+c\left(\frac{\alpha}{1+g^{B}}\right)^{t}-\frac{1+g^{B}}{r-g^{B}}} \frac{1+u^{A}}{1+\alpha}
\end{gathered}
$$

Which $u^{A}$ represents the solvency growth rate of the reserve currency countries. The convergence condition is $r \leq u^{A}$ and $g^{\mathrm{B}} \leq u^{A}$, and in order to guarantee the solvency support ratio $\bar{k}_{t}$ not too big to need reserve currency state solvency $T_{t}^{A}$ should be large enough that the reserve currency countries should have larger economies.

\subsection{Conclusion}

The equilibrium stability condition of reserve currency is that the solvency growth rate of reserve currency countries is not lower than the real yield of reserve currency and the actual output growth rate of the non-reserve currency countries, and the reserve currency countries should have larger economies. 


\section{The stability Condition test of the international reserve currency system}

\subsection{Stability testing of the Bretton Woods system}

Under the Bretton Woods system, currencies pegged to the United States dollar and the dollar to gold remained in fixed exchange rates, so the U.S. as a reserve currency issuer, its solvency in the U.S. Gold reserve growth rate. According to this model, the stable equilibrium condition of reserve currency is that the real yield of us is lower than that of gold reserve, and the real output growth rate of us is higher than that of the non-reserve countries. Remember gus for U.S. Gold Reserve growth, $r_{u s}$ for us real yield, $g^{\text {us }}$ for us real output growth, go is the actual output growth rate for a non-reserve country, then the stable equilibrium condition of the dollar as the international reserve currency can be expressed as follows: GUS $\geq r_{\text {us }}$ and $g^{\text {us }} \geq g^{\circ}$.

The Bretton Woods system was established in the 1944 year 7 month, and it was the end of the week that the Federal Reserve refused to convert gold to other countries ' central banks in the1971 year [month]. However, due to data availability, the time period of data interception in this article is 1951-1972 year. One of the U.S. Gold Reserve growth rate reference to the World Gold Association announced the U.S. 1951-1972 Year of gold reserves; the real growth rate in the United States is derived from the U.S. general economic data Base (the conference Board Total Economy database)GK_GDP sequence , which is based on the 1990 year, denominated in US dollars, and use the purchasing power appraisal method to carry on the corresponding adjustment; the growth rate of the rest of the world is also referenced to the GK_GDP sequence; the real rate of return in the US is calculated by dividing US Treasury yields by the US's CPI index, data from IMF 's IFS (Analyst Financial Statistics) database. Figure I can see the stability of the currency under the Bretton Woods system. By observation, the real yield in the US was higher than that of the U.S. Gold Reserve during the 1951-1972 year, and it was clear that the U.S. Gold Reserve was unable to support the US reserve currency, and that the actual output in the United States was essentially lower than that of the rest of the world. From the above two conditions, in the latter part of the Bretton Woods system, two conditions were not met, especially in the 1970 year, when the real output growth rate in the United States was significantly lower than the real growth rate of the world's other non-reserve currency countries, accelerating the collapse of the Bretton Woods system.

\subsection{Stability test for modern international monetary system}

In the modern international monetary system, the dollar remains the main reserve currency, but the solvency of the reserve currency countries is mainly reflected in the fiscal capacity of the reserve currency countries. And the fiscal capacity of a country is related to the fiscal policy of the government and the economic output of the country. This paper mainly considers the effect of the actual output of American economy on the solvency of the United States. The data sources analyzed at this stage are the same as those in the previous section.

Before the 2008, the real yield of the dollar was higher than the real output growth rate in the United States, which was the main reason for the instability of the international reserve currency system. After the year, the growth rate of real output in the non-reserve countries was significantly higher Is the main reason for the instability of the international monetary system.

\subsection{Conclusions}

Based on the new open Economic analysis framework, this paper analyzes the conditions of the stability of the international monetary system from the perspective of supply and demand of reserve currency. The model analysis shows that the stability of the international monetary system is the condition that the economies of the reserve currency countries are large enough, and the growth rate of solvency of reserve currency countries is not lower than the actual output growth rate of the non-reserve currency countries or the actual yield of reserve currency. The growth rate of solvency of reserve currency countries is often limited, such as gold standard, Gold Exchange Standard and the growth of gold mining under the Bretton Woods system, which is restricted by the growth of fiscal solvency of reserve countries under the modern international monetary system, and the stability conditions of the international monetary system cannot be satisfied.

In accordance with the stability of this article, to enhance the stability of the international reserve currency system, it is necessary to enhance the solvency of the reserve currency issuer or reserve currency issuing group, that is, to enhance the reality of the issuer of the reserve currency output the growth rate and the actual yield of the reserve currency; subsequent studies could further examine whether the current proposed diversification of the reserve-currency scheme relative to a single country's provision of a reserve currency would effectively enhance the reality of the issuer of the reserve currency Output growth rate and the actual yield of reserve currency, thus judging the reform direction of the international reserve currency system.

\section{REFERENCES}

1. Maurice Obstfeld, Jay C. Shambaugh, Alan M. Taylo. Financial Stability, the Trilemma, and International Reserves[J]. NBER Working Paper No.14217. 2008

2. Caballero,Ricardo J,Emmanuel Farhi,Pierre-Olivier Gourinchas . An Equilibrium Model of Global Imbalances and Low Interest Rates. The American Economist . 2008

3. Chen Jianchi . cracking the "Terry" puzzle-the stability of sovereign-credit currencies as an international reserve [J]. Economic Research , 2012,04:113-123.

2523 | P a g e

February 2018

https://cirworld.com 
4. Xu Jianwei , Yao. New forms of international division of labour, financial market development and global imbalances [J]. World Economy , 2010,03:3-30.

5. Obstfeld, Maurice and Rogoff, Kenneth. Foundations of Analysys Macroeconomics. MIT Press, 1996.

6. Farhi E, Gourinchas P O, Rey H. reforming the Analysys monetary System[J]. Wider annual lectures, 2011,52 (3): 53-84.

7. The International Monetary System Living with Asymmetry. Maurice Obstfeld. NBER Working Paper Series . 2011

\section{Author' biography}

Kaida Li, master student in the School of Economic and Resource Management at Beijing Normal University, majored in regional economics and finance. 